\author{
Anna ArtwińsKa \\ (D) https://orcid.org/0000-0001-8069-0627 \\ Institut für Slavistik, Universität Leipzig
}

\title{
Ołowiane żołnierzyki, cynkowe trumny Swietłany Aleksijewicz opowieść o wojnie w Afganistanie i granice świadectwa
}

\author{
Lead Soldiers, Zinc Coffins: Svetlana Alexievich's Afghan Tale \\ and the Limits of Testimony
}

\begin{abstract}
Aвstract: The novel Zinky Boys (1989; Polish editions in 2007 and 2015) by Belarusian author Svetlana Alexievich is more than just a story of the Soviet military intervention in Afghanistan (1979-1989) told from the perspective of the soldiers who participated in it. It also confronts readers with the contractual nature of the line that separates "artistic" and "documentary" prose and probes the complexities of the discourse on memory in Russian culture. This article discusses the key motifs of Zinky Boys: "zinc coffins" and "lead soldiers". It also examines and ponders the reasons for the lawsuit against the author for the publication of passages from the novel. Drawing on Michael Rothberg, Anna Artwińska argues that, in order to be able to understand the drama of the Soviet intervention in Afghanistan, one needs to assume the position of an "implicated subject", i.e., of a person who understands the need for shared ethical responsibility for traumatic past events, even though they neither participated in those events nor witnessed them.
\end{abstract}

KeY WORDS: Soviet intervention in Afghanistan (1979-1989), Svetlana Aleksievich, zinc coffin, collaborative writing, implicated subject 


\section{„Zabawa” w wojnę}

„Ołowiane żołnierzyki” to tradycyjne zabawki dla dzieci, popularne w wielu kulturach i służące do „zabawy” w wojnę. W ich upowszechnieniu dużą rolę odegrała książka Herberta George'a Wellsa Little Wars: a Game for Boys from Twelve Years of Age to One Hundred and Fifty and for That More Intelligent Sort of Girl Who Likes Boys' Games and Books [sic!], opublikowana w 1913 roku. Gra w wojnę zakłada, że żołnierzyki traktuje się trochę tak jak prawdziwych żołnierzy: nie przypadkiem figurki są wyposażone w mundury, broń i ekwipunek wzorowane na uposażeniu stosowanym podczas realnych starć. Poruszane dziecięcą ręką miniaturowe żołnierzyki mają więc walczyć „naprawdę”, są zabawkami, dzięki którym możliwa jest iluzja uczestnictwa w wydarzeniach historycznych ${ }^{1}$. „Mój żołnierzyku / Do ataku idź jak w dym / Zabaw trochę strojne lalki / Nudno im / I nie tchórz w walce / Trąbka gra, maszeruj więc / A gdy zechcę, kiwnę palcem / Zrobisz bęc / A gdy zechcą, kiwną palcem / Zrobię bęc" śpiewał w piosence o ołowianym żołnierzyku Michał Bajor ${ }^{2}$. Niebezpieczeństwo „zabawy” w wojnę świetnie pokazuje film Ołowiane żołnierzyki Maksymiliana Emmera i Jerzego Maliniaka z 1938 roku, w którym ołowiane figurki poddane zostały animizacji. Przedstawiono tu walki pomiędzy dwoma wrogimi obozami zabawek, które kamera ujmuje tak, jak gdyby działy się naprawdę. Ten w moim przekonaniu antywojenny obraz przestrzega przed tym, że „zabawy” w „małe wojny” - by raz jeszcze odwołać się do tytułu książki Wellsa - niepostrzeżenie mogą wywołać apetyt na wojny „duże”.

${ }^{1}$ W opowiadaniu Władysława Bełzy Ołowiany żołnierz główny bohater Staś, który „dostał od taty pudełko ślicznych, ołowianych żołnierzy”, marzył „o podbiciu co najmniej połowy Europy i ciągle tylko dopytywał się u ojca, czy nie ma gdzie w gazetach wiadomości o jakiej wojnie, bo wojsko aż rwie się do bitwy, a sam nie wie na kogo je prowadzić" (W. Bełza: Ołowiany żołnierz. W: Tenże: Ołowiany żołnierz i inne powiastki dla młodego wieku. Gebethner i Wolff, Warszawa 1909, s. 3-4).

${ }^{2}$ M. Bajor: Mój żotnierzyku. Dostępne w Internecie: https://www.michalbajor.pl/index. php?option=com_content\&view=article\&id=116:moj-zolnierzyku\&catid=17:teksty-piosenek\&Ite mid=101 [data dostępu: 18.03.2021]. 
Figurki zabawek są odlewane ze stopu ołowiu i cyny - fakt ten sprawia, że niekiedy ołowiane żołnierzyki nazywa się cynowymi. Każdy, kto choć trochę zna się na chemii, wie, że lepiej być żołnierzykiem cynowym niż ołowianym: ołów jest neurotoksyną, która uszkadza tkanki mięśniowe i krew. Hamuje pracę wielu enzymów i zakłóca dostarczanie tlenu organizmowi oraz pracę nerek. Objawy chronicznego zatrucia ołowiem to bóle głowy, nudności czy utrata wagi ${ }^{3}$. Tych trujących właściwości nie ma cyna - pierwiastek, który choć sam nie szkodzi tak jak ołów, już od czasów starożytności bywa z nim często mylony. Jak podaje Wikipedia: „Rzymianie określali ołów słowami plumbum nigrum (dosłownie ołów czarny), cynę zaś plumbum candidum (ołów jasny). Związek między cyną a ołowiem uwidacznia się także w innych językach: czeskie słowo olovo tłumaczy się jako 'ołów', jednak w języku rosyjskim олово (olovo) oznacza cynę $^{\prime 4}$. Tendencję do traktowania ołowiu i cyny jako synonimów można zresztą zaobserwować także w innych kontekstach. Jest ona widoczna chociażby w polskich przekładach baśni duńskiego pisarza Hansa Christiana Andersena Den standhaftige tinsoldat z 1838 roku, która w Polsce funkcjonuje zarówno pod tytułem Dzielny ołowiany żołnierzyk, jak i Dzielny żołnierz cynowy.

W kontekście pomyłek związanych z cyną i ołowiem interesująca jest historia polskich tłumaczeń książki Цинковые мальчики (2006) białoruskiej pisarki Swietłany Aleksijewicz. Pierwsze polskie wydanie tej „opowieści w dokumentach" ukazało się w 2007 roku w przekładzie Leszka Wołosiuka jako Ołowiane żołnierzyki. Stefan Bratkowski uznał ten tytuł w swojej przedmowie za „nieco mylący”: „Cynkowyje malcziki ukazują się po polsku pod nieco mylącym ty-

${ }^{3}$ Zob. K. Puto: Wielki kapitał chciał nas zatruć ołowiem. Nie tylko on. „Krytyka Polityczna” z 19 marca 2021 r. Dostępne w Internecie: https://krytykapolityczna.pl/swiat/wielki-kapitalchcial-nas-zatruc-olowiem-nie-tylko-on/ [data dostępu: 18.03.2021].

${ }^{4}$ Ołów. Dostępne w Internecie: https://pl.wikipedia.org/wiki/O\%C5\%82\%C3\%B3w\#CITEREFPolyanskiy1986 [data dostępu: 18.03.2021].

${ }^{5}$ Przedstawiona w niej postać dzielnego ołowianego (cynowego) żołnierzyka symbolizuje siłę miłości i prawo do posiadania marzeń - baśń uczy, że nawet jeśli posiada się jakieś ułomności, jak główny bohater, pozbawiony jednej nogi, nie należy się poddawać i rezygnować ze swoich pragnień. Warto w tym miejscu zwrócić uwagę, że postać żołnierzyka jest u Andersena konotowana pozytywnie. W literaturze dla dzieci motyw ołowianych żołnierzyków pojawia się także w Dzieciach z Bullerbyn Astrid Lindgren: w noc sylwestrową dziecięcy bohaterowie odlewają figurki i wróżą z ołowiu przyszłość. 
tułem Ołowiane żołnierzyki. Dla nas ołowiany żołnierz to dziecięca zabawka, podczas gdy rosyjski "cynkowyj malczik» to także zwłoki żołnierza, które przywożono bliskim z frontu z Afganistanu w cynkowej trumnie [...]"6. Jak Wołosiuk wpadł na to tłumaczenie tytułu i dlaczego posłużył się metaforyką dziecięcych zabaw - nie wiadomo. Tłumacz (błędnie) połączył tytułowy cynk z cyną, by następnie uruchomić skojarzenie z cynowymi/ołowianymi żołnierzykami. Czyżby chodziło mu o sugestię, że wysłani do Afganistanu żołnierze byli zabawkami w rękach politycznych dygnitarzy? I jeśli tak - jak to pogodzić z faktem, że starcia w Afganistanie nie były bynajmniej „zabawą” w wojnę, że wydarzyły się naprawdę i pochłonęły mnóstwo istnień ludzkich ${ }^{7}$ ? Czy może Wołosiukowi chodziło raczej o przypomnienie trujących właściwości ołowiu? Nie można też wykluczyć, że tytuł jest nawiązaniem do debiutanckiego tomiku Jerzego Ficowskiego z 1948 roku - Ołowiani żotnierze, w którym wojenna przeszłość przedstawiona została w poetyce baśni. „Na nieprawdziwym tle miasta maszerują - ołowiani - żołnierze" - pisał poeta ${ }^{8}$. Według Jerzego Kandziory

[...] poezja Ołowianych żotnierzy nie zakotwicza się w kręgu wojennych spraw. Właściwie od początku odchyla się ku sferze wyobraźni, baśniowości, ornamentacjom świata, motywom florystycznym, efektom synestezyjnym, feeriom barw i świateł, magii dnia codziennego. Nawet teraz, po wielu latach, podczas lektury książki dotyka nas przez moment to poczucie pewnej niefrasobliwej

${ }^{6}$ S. Bratkowski: Książka o wyobraźni Rosjan. W: S. Aleksijewicz: Ołowiane żołnierzyki. Przeł. L. Wołosiuk. Kolegium Europy Wschodniej im. Jana Nowaka-Jeziorańskiego, Wrocław 2007, s. 5.

${ }^{7}$ Jako motto do książki Aleksijewicz podaje krótkie zestawienie faktograficzne: „W grudniu 1979 roku kierownictwo radzieckie zdecydowało się wprowadzić wojsko do Afganistanu. Wojna trwała do 1989 roku, ciągnęła się dziewięć lat, jeden miesiąc i dziewiętnaście dni. Przez Afganistan przeszło ponad pół miliona żołnierzy ograniczonego kontyngentu wojsk radzieckich. Straty Sił Zbrojnych Związku Radzieckiego wyniosły w sumie piętnaście tysięcy pięćdziesięciu jeden ludzi. Zaginęło bez wieści bądź trafiło do niewoli czterystu siedemnastu żołnierzy. Do roku 2000 dwieście osiemdziesiąt siedem osób wciąż nie wróciło do domu, a ich los jest nieznany" (S. Aleksijewicz: Cynkowi chłopcy. Przeł. J. Czech. Wydawnictwo Czarne, Wołowiec 2015, lok. 8; wszystkie cytaty z tej publikacji podaję za wydaniem elektronicznym).

${ }^{8}$ J. Ficowski: Każdy ślad cieniem wyrasta. W: Tenże: Ołowiani żołnierze. Wydawnictwo Eugeniusza Kuthana, Warszawa-Kraków 1948, s. 4. 
bezzwłoczności, z jaką poetyckie theatrum wyobraźni wnika w krajobraz ruin, elegijną tonację wierszy ${ }^{9}$.

Przekład Wołosiuka zastanawia tym bardziej, że Aleksijewicz nie odwołała się w swojej książce ani razu do motywu zabawy figurkami odlewanymi ze stopu ołowiu i cyny, w języku rosyjskim określanymi mianem солдатики. Bohaterowie jej opowieści nie zostali nazwani w tytule żołnierzami (ani tymi bardziej żołnierzykami), tylko chłopcami - cynkowymi chłopcami, ponieważ z cynku były robione trumny dla tych, którym nie udało się przeżyć walk w Afganistanie. Autorka pisze: „Przecież wojna trwała już siódmy rok... Tyle że nie wiedzieliśmy o niej nic poza tym, co pokazywały dziarskie reportaże telewizyjne. Od czasu do czasu wzdrygaliśmy się na widok przywiezionych $\mathrm{z}$ daleka cynkowych trumien, które nie mieściły się w piórnikowych gabarytach naszych »chruszczowców«"10.

Opublikowane w 2015 roku drugie wydanie książki Aleksijewicz (w przekładzie Jerzego Czecha) nosi już zgodny z oryginałem tytuł Cynkowi chłopcy. Rzeczownik „ołów” występuje w tej edycji zaledwie kilka razy - tam, gdzie w rosyjskim oryginale pojawia się słowo свинец. Ołów (свинеи), choć w tekście Aleksijewicz nie jest kluczowy, może zostać uznany za metonimię wojny - nie tej, w którą bawią się żołnierzykami mali chłopcy, ale tej prawdziwej, która rozegrała się w Afganistanie od 1979 do 1989 roku i która uważana jest za jeden z najkrwawszych konfliktów XX wieku. Toksyczny ołów występował w wykorzystywanych podczas tej wojny kulach i pociskach, żołnierze kojarzyli go więc jednoznacznie ze śmiercią. W relacji jednego z majorów - dowódcy batalionu, czytamy: „Cały czas miałem uczucie, że ktoś mnie chce zabić. Głupi ołów... Do dzisiaj nie wiem, czy można się do tego przyzwyczaić. A melony, arbuzy są tam

${ }^{9}$ J. Kandziora: Tropy akowskie $w$ poezji Jerzego Ficowskiego. „Poznańskie Studia Polonistyczne" 2012, nr 20 (40), s. 253.

${ }^{10}$ S. Aleksijewicz: Cynkowi chłopcy..., lok. 23. Na temat różnic i podobieństw między przekładami Wołosiuka i Czecha zob. A. Szczęsny: „Ołowiane żołnierzyki” czy „Cynkowi chłopcy”? Przypisy tłumacza jako kryterium analizy serii tłumaczeniowej. „Między Oryginałem a Przekładem” 2016, nr 2 (32), s. 103-119. 
takie wielkie jak taborety. Jak się nakłuje bagnetem, to pękają. Umierać jest tak łatwo. Trudniej zabijać"1.

\section{„Sowiecki Wietnam”}

Białoruska pisarka Swietłana Aleksijewicz wielokrotnie poruszała w swojej twórczości problem katastrof XX wieku. Pisała o drugiej wojnie światowej z perspektywy uczestniczących w niej kobiet - żołnierek, snajperek, strzelczyń czy pielęgniarek; opisywała tragedię wybuchu w elektrowni atomowej w Czarnobylu, oddając głos tym, których dotknęła ona w najbardziej dosłowny sposób, a więc białoruskim mieszkańcom regionu; reportażystka zebrała i opracowała także wspomnienia weteranów wojny w Afganistanie. Cechy jej pisarstwa: eklektycznego, gdyż łączącego reportaż i świadectwo z artystyczną kreacją; emocjonalnego i afektywnego, ponieważ stawiającego w centrum ofiary; wreszcie społecznie zaangażowanego, dążącego do ujmowania „wielkiej historii” przez pryzmat „Zwykłego człowieka” - były już wielokrotnie przedmiotem dogłębnych analiz, zarówno w Polsce, jak i za granicą ${ }^{12}$. $Z$ tego powodu nie ma potrzeby ich jeszcze raz przypominać - wystarczy poprzestać na stwierdzeniu, że w ostatecznym rozrachunku Aleksijewicz pozostaje pisarką osobną, której

${ }^{11}$ S. Aleksijewicz: Cynkowi chłopcy..., lok. 412.

${ }^{12}$ Zob. m.in. poświęcony pisarce numer specjalny czasopisma „Osteuropa“: „Osteuropa“ 2018, Nr. 1-2: Nackte Seelen Svetlana Aleksievič und der „Rote Mensch“. Hrsg. M. Sapper, A. Tippner, V. Weichsel. Twórczością białoruskiej autorki zajmowałam się w następujących artykułach: A. Artwińska: Gewalt legitimieren? Krieg und Affekte bei Svetlana Aleksijevič. In: Verbrechen, Fiktion, Vermarktung. Gewalt in den zeitgenössischen slavischen Literaturen. Hrsg. L. Burlon i in. Universitätsverlag Potsdam, Potsdam 2013, s. 161-175; A. Artwińska: We're Easy to Spot': Soviet Generation(s) after Soviet Era and the Invention of the Self in Svetlana Alexievich's "Secondhand Time: The Last of the Soviets". In: Gender, Generations, and Communism in Central and Eastern Europe and Beyond. Eds. A. Artwińska, A. Mrozik. Routledge, New York-London 2020, s. 227-247. 
twórczość wymyka się jednoznacznym definicjom i klasyfikacjom ${ }^{13}$. W artykule będą mnie interesowały nie tyle artystyczne cechy jej utworów, ile raczej recepcja Cynkowych chłopców. Warto przypomnieć, że już po publikacji fragmentów książki w prasie byli żołnierze i rodziny ofiar wytoczyli autorce proces sądowy, zarzucając jej nie tylko zszarganie pamięci o wojnie, ale także manipulowanie świadectwami swoich rozmówców. Sprawozdania z procesu zostały załączone do książki - nie jako aneks, ale jako jej immanentna część: „opowieść w dokumentach". Ich lektura, po pierwsze, pozwala uświadomić sobie, jak trudno przełamać oficjalny sowiecki/rosyjski dyskurs o starciach w Afganistanie, po drugie zaś - uwrażliwia na etyczne problemy związane z samym aktem składania świadectwa.

Wytoczony Aleksijewicz proces to nie pierwszy przypadek wykorzystania tekstu literackiego w sądzie - polskim czytelnikom najpewniej znana jest historia wiersza Zuzanny Ginczanki zaczynającego się od incipitu Non omnis moriar, który stał się dowodem sądowym w sprawie przeciwko Zofii Chominowej, dozorczyni ze Lwowa, w czasie drugiej wojny światowej donoszącej Niemcom na ukrywających się w jej kamienicy Żydów ${ }^{14}$. W obu przypadkach - Ginczanki i Aleksijewicz - tekst literacki opuścił domenę literatury, stając się przedmiotem rozważań z zakresu prawa, sądownictwa i jurysdykcji. O ile jednak w pierwszym przypadku proces miał doprowadzić do ukarania winnych i zapewnić Ginczance pośmiertne zadośćuczynienie, o tyle $\mathrm{w}$ drugim procesie chodziło o to, czy autorka dopuściła się nadużycia, przerabiając w swojej opowieści historie walczących w Afganistanie żołnierzy. Aleksijewicz spotkał więc podobny los jak wcześniej George’a Orwella czy Salmana Rushdiego: została postawiona przed koniecznością wytłumaczenia się ze swojej działalności artystycznej. Do tego problemu wrócę w następnej części artykułu.

W Cynkowych chłopcach Aleksijewicz zebrała wspomnienia tych, którzy przeżyli wojnę w Afganistanie: w pierwszej kolejności żołnierzy, ale także pielę-

${ }^{13}$ Choć można oczywiście wskazać tradycje tej twórczości. Pisarka często określa się mianem uczennicy Daniiła Granina i Alaksandra Adamowicza, autorów Księgi blokady (1979). Książka ta składa się z relacji osób, które w czasie drugiej wojny światowej znalazły się w oblężonym przez Niemców Leningradzie.

${ }_{14}$ Zob. A. Haska: „Znałam tylko jedną żydóweczkę ukrywająca się...”. Sprawa Zofii i Mariana Chominów. „Zagłada Żydów. Studia i Materiały” 2008, nr 4, s. 392-407. 
gniarek i pracownic cywilnych na froncie. W oficjalnej sowieckiej/rosyjskiej kulturze pamięci wojna ta - nie przypadkiem nazywana sowieckim Wietnamem była przedstawiana jako misja pokojowa. „A w Związku Radzieckim telewizja pokazuje, jak w Afganistanie sadzi się aleje przyjaźni, których tutaj nikt $\mathrm{z}$ nas nie sadził ani nawet nie widział...”; „W gazetach pisano, że nasi żołnierze budują mosty, sadzą aleje przyjaźni, a nasi lekarze leczą afgańskie kobiety i dzieci”15 pisze z goryczą Aleksijewicz. Wspomnienia bezpośrednich uczestników wojny zostały uzupełnione o relacje współświadków - rodzin poległych, oraz o notatki autorki, sporządzone częściowo $\mathrm{w}$ trakcie działań wojennych w Taszkencie i Kabulu, częściowo po powrocie do ZSRR. Intencją pisarki było pokazanie okrucieństwa wojny oraz próba odpowiedzi na pytanie, dlaczego tylu młodych Rosjan, pochodzących głównie z terenów dzisiejszej Białorusi i Ukrainy, wzięło udział w operacji wojskowej i jak to możliwe, że po powrocie $\mathrm{z}$ wojny nie tylko nie udzielono im odpowiedniej pomocy psychologicznej i materialnej, ale także nie pozwolono im na wyartykułowanie swoich doświadczeń w przestrzeni publicznej, każąc im zamiast tego powtarzać oficjalne slogany o „internacjonalistycznym obowiązku”. Wiele uwagi poświęciła autorka matkom żołnierzy - tych, których szczątki wróciły do domu w cynkowych trumnach, i tych, którzy choć wojnę przeżyli, okazali się niezdolni do życia. Tym samym można powiedzieć, że Cynkowi chłopcy to częściowo opowieść matriarchalna, akcentująca punkt widzenia kobiet mierzących się ze stratą swoich dzieci. Tak jak w poprzednich książkach autorka wchodzi w rolę zbieraczki głosów i empatycznej słuchaczki, stara się swoich rozmówców skłonić do tego, by podzielili się z nią pamięcią o wojnie - traumatyczną, pełną luk i szczelin oraz rewidującą mity oficjalnego dyskursu. Nie przypadkiem akcent rozmów spoczywa na dramacie wojny Cynkowi chłopcy są opowieścią głęboko pacyfistyczną i antywojenną. Przez większość historii przewija się obraz krwi, zabijania i śmierci; codzienność wojenna jest tu atawistyczną walką o przeżycie. Podkreślane są katastrofalne warunki, w jakich musiano prowadzić operacje militarne, brak odpowiedniego ekwipunku oraz niedostatki w wyżywieniu. Najstraszniejsze i najtrudniejsze do zrozumienia okazuje się jednak to, co za Hannah Arendt nazwałabym banalnością zła, a więc bezrefleksyjne, mechaniczne zabijanie.

\footnotetext{
${ }^{15}$ S. Aleksijewicz: Cynkowi chłopcy..., lok. 42, 56.
} 
Zabijanie to po prostu naciskanie na spust. Uczono nas, że kto strzeli pierwszy, ten przeżyje. Takie jest prawo wojny. [...] Strzelaliśmy w tę stronę, w którą nam kazano. Nauczyli mnie strzelać do tego, co mi wskażą. Strzelałem, nie litowałem się nad nikim. [...] Każdy starał się przeżyć. Nie było czasu na myślenie. Mieliśmy po osiemnaście-dwadzieścia lat. Przywykłem do cudzej śmierci, bałem się tylko własnej. Widziałem, jak z człowieka w sekundzie nie zostaje nic, jakby go w ogóle nie było. W pustej trumnie wysyłano wtedy rodzinie paradny mundur ${ }^{16}$

- czytamy w relacji obsługującego granatnik szeregowego. Dla wszystkich tych, którym udało się przeżyć walki w Afganistanie, powrót do ZSRR bynajmniej nie oznaczał nowego początku. Wręcz przeciwnie, retroaktywna siła wojny uniemożliwiała byłym żołnierzom odcięcie się od przeszłości. „Proszę mi tylko nie wmawiać, że ta wojna się skończyła”; „ta wojna dla mnie nigdy się nie skończy..." - zapewniali pisarkę weterani ${ }^{17}$. Także dla ich rodzin życie "po” Afganistanie okazywało się życiem w cieniu tej katastrofy, tym trudniejszym, że w sowieckiej/rosyjskiej kulturze nie było gotowości do zmierzenia się z własną winą i własnym sprawstwem, brakowało również języka, za pomocą którego można by o tych doświadczeniach mówić. Od weteranów oczekiwano kontynuacji etosu i habitusu żołnierzy wielkiej wojny ojczyźnianej, a więc tego, że będą w szkołach i na okolicznościowych spotkaniach opowiadać o swoim męstwie i bezgranicznym oddaniu ojczyźnie. Tymczasem ci, którzy przeżyli wojnę w Afganistanie, nie byli w stanie nadać temu doświadczeniu żadnego wyższego sensu ani też zintegrować go we własną, autobiograficzną narrację. Prowadziło to do sytuacji permanentnego konfliktu: między publicznym a prywatnym, między wiernością dowódcom a pamięcią o tych, którzy do domu wrócili w cynkowych trumnach, między koniecznością odgrywania iluzji nowego początku a mentalnym uwięzieniem w przeszłości.

Cynkowi chłopcy Aleksijewicz to interesujący przykład narracji świadków. Pisarka nie rozmawia $\mathrm{z}$ afgańskimi ofiarami wojny, nie dąży do ukazania perspektywy drugiej strony; w centrum jej uwagi znajduje się pamięć sowieckich żołnierzy. Większość z nich miała świadomość własnej winy, równocześnie

\footnotetext{
16 Tamże, lok. 58.

17 Tamże, lok. 83, 389.
} 
jednak sytuowała się w roli ofiar - zarówno samej wojny, jak i sowieckiej propagandy, z powodu której zdecydowała się na udział w misji. Zwielokrotniona tożsamość „afgańców” to dowód na to, że granica pomiędzy sprawcą, świadkiem a ofiarą może stać się bardzo płynna. Okaleczeni psychicznie i fizycznie żołnierze sowieckiej misji w Afganistanie byli sprawcami, świadkami i ofiarami równocześnie, przy czym najczęściej zrastali się z tymi rolami na zawsze.

Czytając zebrane przez Aleksijewicz relacje, trudno nie pomyśleć o koncepcji „Zaangażowanego/uwikłanego podmiotu” (implicated subject) Michaela Rothberga, ukutej na określenie sytuacji uwikłania w wydarzenia, które na pierwszy rzut oka znajdują się poza zasięgiem własnej sprawczości. Według Rothberga „wspólna odpowiedzialność za czyny, których nie popełniliśmy”18, jest warunkiem niezbędnym do stworzenia globalnej, transnarodowej pamięci o przeszłości, dzięki której możliwe będzie uniknięcie konkurencji pomiędzy partykularnymi narracjami i doświadczeniami. Opierając się na teoriach Karla Jaspersa i Hannah Arendt dotyczących „winy kryminalnej” i współuczestnictwa, Rothberg postuluje konieczność przejmowania szeroko rozumianej odpowiedzialności za przeszłość, a więc identyfikacji nieograniczającej się do doświadczeń związanych z historiami narodowymi. W kontekście Cynkowych chłopców można by, jak sądzę, potraktować koncepcję Rothberga jako zaproszenie do refleksji nad wojnami, toczonymi w XX wieku i obecnie, oraz do przemyślenia związanych z nimi podmiotowych uwikłań. Aleksijewicz opowieść o Afganistanie jest wszak z jednej strony opowieścią mającą bardzo konkretnych bohaterów i rozgrywającą się w bardzo konkretnej czasoprzestrzeni. Z drugiej strony jej wymowa jest uniwersalna - przemoc, jak wiadomo, wydarza się w najróżniejszych historycznych i kulturowych dekoracjach. Polska korespondentka wojenna Maria Wiernikowska rekomendowała polski przekład książki Aleksijewicz następująco:

Kogo obchodzi dziś radziecki Afganistan? Nie zapominajmy, że po Rosjanach weszli tam nasi sojusznicy Amerykanie. My też mieliśmy naszych chłopców w Nangar Chel. „Zapomnienie jest [...] formą kłamstwa”. Tu oprawcami są

${ }^{18}$ M. Rothberg: The Implicated Subject. Beyond Victims and Perpetrators. Stanford University Press, Stanford 2019, s. 1 (jeśli nie wskazuję inaczej, cytaty obcojęzyczne podaję w swoim tłumaczeniu - A.A.). Cytat ten Rothberg przywołuje z pracy H. Arendt o odpowiedzialności zbiorowej. 
Rosjanie, karmieni literaturą i wódką. „Ale wszyscy jesteśmy winni, wszyscy uczestniczyliśmy w tym kłamstwie" - mówi autorka. I jeszcze: na wojnie zawsze wszyscy jesteśmy ofiarami ${ }^{19}$.

Żeby nie zapomnieć, warto czytać Cynkowych chłopców jako dokument i metatekst równocześnie.

\section{Granice świadectwa}

„Aleksijewicz całkowicie zniekształciła moją relację, dopisała rzeczy, których nie mówiłem, jeśli zaś mówiłem, to inaczej je rozumiałem; wyciągnęła wnioski, które są całkiem odmienne od moich własnych" - tymi słowami skierowany przeciw pisarce pozew o zniesławienie i odszkodowanie uzasadnił jeden $\mathrm{z}$ jej wcześniejszych rozmówców ${ }^{20}$. Warto przypomnieć, że do procesu sądowego przeciw autorce Cynkowych chłopców doszło z inicjatywy matek żołnierzy, oburzonych opublikowanymi w „Komsomolskiej Prawdzie” fragmentami książki oraz wystawionym na ich podstawie spektaklem teatralnym. Do złożonego przez grupę matek pozwu dołączyli z czasem także inni uczestnicy wojny. W trakcie kilku rozpraw, których stenogramy załączono do książki, pisarka musiała mierzyć się z zarzutami celowego zniekształcania wspomnień weteranów, szkalowania pamięci o poległych żołnierzach oraz, last but not least, czerpania korzyści finansowych z rozpowszechniania doświadczeń ofiar. Oskarżyciele domagali się korekty tekstu oraz wypłaty odszkodowań. W obronie pisarki stanęli przedstawiciele nauki i kultury, listy poparcia wystosowali między innymi Stowarzyszenie Związku Pisarzy Rosyjskich oraz rosyjski i białoruski PEN Club. Jako że sąd oddalił prośbę pisarki o poddanie tekstu ekspertyzie literackiej i uwzględnienie kryteriów literackich przy formułowaniu wyroku, wiceprezes białoruskiego PEN Clubu z własnej woli wystosował prośbę o opinię

${ }^{19}$ Wypowiedź przytoczona za stroną internetową Wydawnictwa Czarne: https://czarne.com. $\mathrm{pl} / \mathrm{katalog} / \mathrm{ksiazki} / \mathrm{cynkowi-chlopcy} \mathrm{[data} \mathrm{dostępu:} \mathrm{18.03.2021].}$

${ }^{20}$ S. Aleksijewicz: Cynkowi chłopcy..., lok. 486. 
do Białoruskiej Akademii Nauk. Pracownik BAN W.A. Kowalenko poproszony został o przygotowanie odpowiedzi na następujące pytania:

1. Jak naukowo określa się gatunek opowieści dokumentalnej, przy czym słowo „dokumentalna” rozumieć tu należy: „na podstawie faktów (świadectw)”, a słowo „opowieść" - jako „dzieło artystyczne”?

2. Czym różni się opowieść dokumentalna od publikacji w gazecie lub czasopiśmie, w szczególności od wywiadu, którego tekst zazwyczaj autor pokazuje rozmówcy?

3. Czy autor opowieści dokumentalnej ma prawo do użycia środków artystycznych, do własnej koncepcji dzieła, do wyboru materiałów, do literackiego opracowania relacji ustnych, do własnego światopoglądu, do uogólniania faktów w imię prawdy artystycznej?

4. Kto jest właścicielem praw autorskich: autorka czy też bohaterowie opisanych przez nią wydarzeń, których to bohaterów spowiedzi-świadectwa nagrała $\mathrm{w}$ trakcie zbierania materiałów?

5. Jak określić granice, w których autor jest wolny od dosłowności, konieczności mechanicznego przekazu nagranych tekstów?

6. Czy książka S. Aleksijewicz Cynkowi chłopcy należy do gatunku opowieści dokumentalnej (w związku z pytaniem pierwszym)?

7. Czy autor opowieści dokumentalnej ma prawo zmieniać imiona i nazwiska swoich bohaterów?

8. Wreszcie, jako wniosek z tych wszystkich pytań, najważniejsze z nich: czy można stawiać przed sądem pisarza za fragment dzieła literackiego nawet wtedy, kiedy ów fragment nie podoba się tym, którzy dostarczyli ustnego materiału do książki? S. Aleksijewicz opublikowała nie wywiad z powodami, ale właśnie fragment $\mathrm{z}$ książki o charakterze opowieści dokumentalnej ${ }^{21}$.

Mimo że wszystkie odpowiedzi były jednoznacznie korzystne dla pisarki poproszony o ekspertyzę naukowiec podkreślił, iż choć książka ma charakter dokumentu, to jest także kreacją autorską (gdyż to Aleksijewicz jest instancją porządkującą materiał), w związku z czym musi być traktowana jako literatura, a nie jak materiał z zakresu oral history - to jednak nie wyczerpały one całkowicie problemu, z jakim konfrontuje nas tekst Cynkowych chłopców i który

\footnotetext{
${ }^{21}$ Tamże, lok. 587-589.
} 
stał się podstawą procesu. Chodzi tu z jednej strony o etyczne i prawne kwestie pisarstwa kolaboratywnego jako takiego, $\mathrm{z}$ drugiej strony - o ambiwalencje związane $\mathrm{z}$ aktem składania świadectwa.

Teoretycy tzw. pisarstwa kolaboratywnego: Philippe Lejeune, Thomas G. Couser i Mark A. Sanders, zwracają uwagę na to, że powstałe we współpracy dwóch lub więcej osób teksty implikują wiele problemów ${ }^{22}$. I tak, kapitał kulturowy ich uczestników rzadko rozkłada się symetrycznie (w przypadku Cynkowych chłopców znajduje się on zdecydowanie po stronie pisarki), co może prowadzić do różnego rodzaju zależności i nierówności. Tym samym osoba, która porządkuje badaną biografię oraz nadaje jej narracyjną ramę, musi mierzyć się z problemami natury artystycznej i etycznej jednocześnie. Trudne do rozstrzygnięcia jest także to, kto powinien teksty kolaboratywne autoryzować i komu przysługuje honorarium autorskie. Problemów tych nie da się rozwiązać ryczałtowo, gdyż pisarstwo kolaboratywne jest bardzo różnorodne - opowieści dokumentalne Aleksijewicz nie są tym samym, co, przykładowo, rozmowy między pisarzem Karelem Čapkiem a prezydentem Tomaszem G. Masarykiem. Warto jednak każdorazowo szukać odpowiedzi i rozwiązań, gdyż dzięki nim można zrozumieć specyfikę tekstów pisanych przez więcej niż jedną osobę. Do procesu wytoczonego Aleksijewicz doprowadziła wszak nie tylko urażona duma, ale również niezrozumienie reguł gry czy może ich niedoprecyzowanie. Dla pisarki było jasne, że mimo tego iż w swojej pracy opiera się ona na wypowiedziach dokumentalnych i stosuje technikę przytaczania cytatów w mowie niezależnej oraz bezpośredniego oddawania głosu swoim bohaterom, to jednak tworzy własną książkę autorską. Akt interpretacyjny odbywa się tu poprzez selekcję materiału i kompozycję, jest także obecny w paratekstach - notatkach i komentarzach pisarki. Nie przypadkiem Aleksijewicz zdecydowała się nie podpisywać poszczególnych relacji imionami i nazwiskami bohaterów, ograniczając się do podania nazwy stopnia czy pełnionej funkcji. Z kolei z perspektywy

${ }^{22}$ Ph. Lejeune: Die Autobiographie der Nicht-Schreiber. In: Texte zur Theorie der Biographie und Autobiographie. Hrsg. A. Tippner, Ch.F. Laferl. Reclam, Stuttgart 2016, s. 191-218; Th.G. Couser: Making, Taking, and Faking Lives. The Ethics of Collaborative Life Writing. "Style. Literature and Ethical Criticism" 1998, no 32/2, s. 334-350; M.A. Sanders: Theorizing the Collaborative Self: The Dynamics of Contour and Content in the Dictated Autobiography. "New Literary History" 1994, Vol. 25, no 2: Writers on Writers, s. 445-458. 
rozmówców, jak wynika ze stenogramów procesu, rola autorki miała się sprowadzać do wiernego przytoczenia ich wypowiedzi w książce - tak jak dzieje się to przykładowo $\mathrm{w}$ wywiadach. $\mathrm{Z}$ tego powodu czuli się oni uprawomocnieni do autoryzowania własnych wypowiedzi oraz krytykowania ewentualnych przeinaczeń i przeróbek; z tej samej przyczyny rościli pretensje do otrzymanego przez autorkę honorarium. Konflikt ten pokazuje, że w przypadku Cynkowych chłopców problem polegał nie tyle na tym, czy i na ile autorka rzeczywiście zmieniła teksty swoich rozmówców ${ }^{23}$, ile raczej na tym, że na początku nie zostały jasno ustalone zasady współpracy. Tak jak można pomylić cynę z ołowiem, tak można pomylić dokument $\mathrm{z}$ literaturą.

Akt składania świadectwa jest każdorazowo praktyką, w której dochodzi do przecinania się wiedzy i etyki. By zeznania świadków mogły zostać potraktowane jako wiarygodne, potrzebne są zaufanie i dobra wola, gdyż nawet jeśli świadectwa sprawiają wrażenie rzetelnych, nie można wykluczyć omylności ludzkiego umysłu oraz tego, że w bardzo ograniczonym stopniu możemy polegać na swojej pamięci ${ }^{24}$. Białoruski sąd uznał część złożonych w sądzie świadectw za wiarygodne i nakazał autorce podjęcie odpowiednich kroków naprawczych; część pozwów została $\mathrm{z}$ kolei oddalona. Stenogramy rozprawy sądowej pokazują, że ustalenie ostatecznej „prawdy” było przedsięwzięciem niemalże niemożliwym: weterani powoływali się na własną pamięć i doświadczenie, autorka zaś na przeprowadzone wcześniej rozmowy, które stały się podstawą książki. Argumenty Aleksijewicz, że protesty przeciwko jej utworowi wynikają z opresyjności postsowieckiej kultury, wywierającej nacisk na weteranów i każącej im

\footnotetext{
${ }^{23}$ „Tak czy inaczej, należy pamiętać, że wszystkie zawarte w książce świadectwa to wynik dokonanej przez Aleksijewicz interpretacji oryginalnych relacji. Oznacza to, że są one literacką konstrukcją, a nie dosłowną transkrypcją wywiadów" (J. Lindbladh: The Problem of Narration and Reconciliation in Svetlana Aleksievich's Testimony "Voices from Chernobyl". In: The Poetics of Memory in Post-Totalitarian Narration. Ed. J. Lindbladh. Centre for European Studies, Lund 2008, s. 48) - stwierdzenie Johanny Lindbladh dotyczące Czarnobylskiej modlitwy... można odnieść do właściwie wszystkich tekstów białoruskiej pisarki. Badaczka zwraca także uwagę na różnice występujące pomiędzy poszczególnymi wydaniami książek Aleksijewicz, co również potwierdza tezę o konstrukcyjnym i artystycznym charakterze jej pisarstwa.

${ }^{24}$ Zob. S. Krämer: Vertrauen schenken. Über Ambivalenzen der Zeugenschaft. In: Politik der Zeugenschaft. Zur Kritik einer Wissenspraxis. Hrsg. S. Schmidt, S. Krämer, R. Voges. Transcript, Bielefeld 2011, s. 117-139.
} 
dopasować swoją opowieść do obowiązujących oficjalnie ram pamięci, okazały się niemożliwe do potwierdzenia. Proces nie wpłynął na publikację tomu - jak wszystkie wcześniejsze prace autorki także Cynkowi chłopcy ukazali się nie tylko po rosyjsku, ale również w wielu przekładach - stał się jednak pretekstem do rozważań o granicach dokumentu i literatury oraz (nie)możności pełnej weryfikacji świadectw.

W wypowiedzi sądowej pisarka zwracała uwagę na to, „że dokument w sztuce to nie zaświadczenie z komisji wojskowej ani też bilet tramwajowy", oraz że „dokument jest tym, co mi opowiadają inni; dokument, jego część, jest także mną jako artystą mającym swoje własne postrzeganie, odczuwanie świata"25. Podkreślając współczucie dla ofiar „sowieckiego Wietnamu”, zwłaszcza zaś solidarność z matkami poległych, Aleksijewicz nie odniosła się jednak do tego, czy i na ile wprowadziła rozmówców w tajniki własnego warsztatu oraz czy ustaliła $\mathrm{z}$ nimi, jak zostaną zmodyfikowane podczas procesu redakcji nagrane czy zapisane relacje. Fakt, że stosowana przez autorkę metoda sprawdziła się we wcześniejszych (oraz późniejszych) książkach, nie oznacza, że jest ona sama w sobie absolutnie transparentna; tym bardziej że pisarka bardzo często nazywa samą siebie „kronikarką”, jedynie zbierającą i zapisującą głosy innych. „Nikogo nie zmuszam, sami mówią" - czytamy w wywiadzie z Agnieszką Wójcińską ${ }^{26}$.

Rozmówcy Aleksijewicz to typowi „nie-piszący” (Lejeune), a więc osoby skazane na pomoc osób trzecich w pracy autobiograficznej. To, że część z nich nie rozpoznała (czy może raczej: nie chciała rozpoznać) własnego głosu w opublikowanej książce, z pewnością należy wiązać z presją społecznej cenzury i zwykłym ludzkim strachem przed odrzuceniem ${ }^{27}$. Na poziomie teoretycznym uwidacznia się tu jednak pewien szerszy problem, który Lejeune omówił w odniesieniu do autobiografii pisanych we współpracy z kimś, mianowicie fakt „zakłócenia” autobiograficznego systemu. O ile bowiem w klasycznej autobiografii podmiot

${ }^{25}$ S. Aleksijewicz: Cynkowi chłopcy..., lok. 573.

${ }^{26}$ A. Wójcińska: Nikogo nie zmuszam, sami mówią. [Rozmowa ze Swietłaną Aleksijewicz]. „Polityka” 2015, nr 42, s. 38-42.

27 „Cynkowi chłopcy” mieli świadomość wykluczających mechanizmów sowieckiej/rosyjskiej kultury. W jednej z relacji czytamy: „Mówią o nas: ‘afgańcy’. To sygnalizuje obcość. Jak znak. Metka. Że nie jesteśmy tacy jak wszyscy. Jesteśmy inni” (S. Aleksijewicz: Cynkowi chłopcy..., lok. 62). 
narracji jest jedyną instancją sprawczą, tak w autobiografiach podwójnych „we wnętrzu tego samego ja znajdują się dwie osoby"28. I choć Cynkowi chłopcy nie są klasycznym tekstem autobiograficznym, to jednak także w tej książce konstrukcja wypowiedzi autobiograficznej powstaje dwuetapowo: po złożeniu świadectwa przez świadków następuje proces selekcji materiału przez autorkę. Same w sobie trudne do wyartykułowania procesy pamięci poszczególnych podmiotów stają się dzięki temu „własnością” zarówno tych, którzy je przywołują, jak i tej, która je przenosi na papier. Kluczowe założenia pisarstwa autobiograficznego: prawda, autentyczność i autorstwo, zyskują dzięki temu nowe znaczenia.

\section{Zakończenie}

Na koniec rozważań chciałabym wrócić do „mylącego” tytułu pierwszego polskiego przekładu zajmującej mnie książki. Wojna w Afganistanie nie była „zabawą" w wojnę, jednak biorący w niej udział żołnierze rzeczywiście często okazywali się zabawkami w rękach polityków. Tragedię losu „ołowianych żołnierzyków" wyjątkowo wyraźnie pokazuje sposób ich pochówku. Cynkowe trumny ze szczątkami poległych traktowane były jak „skrzynie $\mathrm{z}$ amunicją”; "przywożono do domów te cynkowe trumny, zwracano oszołomionym rodzicom pokaleczone dzieci”; „poległych grzebano po cichu, w nocy, na nagrobkach pisano, że 'umarł', a nie że 'zginą'”'29. Z pewnością cynkową trumnę należy uznać za symbol sowieckiego/rosyjskiego imaginarium wojny w Afganistanie. W oficjalnych dokumentach na jej określenie używano terminu гpyз 200 - „ładunek dwieście”30. W swojej opowieści pisarka zagląda niejako pod wieka owych

${ }^{28}$ Ph. Lejeune: Die Autobiographie der Nicht-Schreiber..., s. 196.

${ }^{29}$ S. Aleksijewicz: Cynkowi chłopcy..., lok. 111, 538, 55.

${ }^{30} \mathrm{Na}$ marginesie warto wspomnieć, że historię powracających do kraju afgańskich trumien w poruszający sposób przedstawił rosyjski reżyser Aleksiej Bałabanow w filmie Ładunek 200 z 2007 r. W recenzji tejże produkcji Wacław Radziwinowicz pisał: „Całe szczęście, że kino przekazuje tylko obrazy i dźwięki. Gdyby przekazywało też zapachy, mielibyśmy jeszcze narastający trupi odór” (Tenże: „Eadunek 200”. Ten ohydny wspaniały ZSRR. „Gazeta Wyborcza” 
cynkowych trumien, sprawdzając, w jakim stopniu kultura rosyjska jest gotowa na zmierzenie się $\mathrm{z}$ poniesioną $\mathrm{w}$ Afganistanie śmiercią młodych żołnierzy. Bilans nie wypada pozytywnie: w latach 90. społeczeństwo nie było otwarte na poznanie prawdziwej dramaturgii tej wojny, nie istniał także żaden dyskurs pamięci, w który można by tę historię ująć. Niemniej znaczenie dokumentalnej opowieści autorki Czarnobylskiej modlitwy... trudno przecenić: narracje świadków są każdorazowo bazą dla praktyk komemoracyjnych przyszłych pokoleń. Badaczka traumy Doris Laub zwracała uwagę na dialogiczny charakter świadectwa, którego odziaływanie rozwija się przez kontakt $\mathrm{z}$ uczestniczącymi w akcie jego składania lub też mierzącymi się $\mathrm{z}$ nim intelektualnie ${ }^{31}$.

Brak świadectw uniemożliwia transgeneracyjną pracę pamięci. W tym miejscu warto powrócić do przywołanej wcześniej koncepcji implicated subject Michaela Rothberga: żeby praca pamięci mogła się odbywać, potrzebne są mianowicie oprócz świadectw także zaangażowane podmioty, podejmujące trud myślenia z perspektywy „afirmatywnego” i „krytycznego” internacjonalizmu ${ }^{32}$. Destabilizacja binarnych podziałów na sprawców i ofiary nie musi prowadzić do relatywizacji czy uniwersalizacji zbrodni, ale raczej może otwierać nowe perspektywy dla współczesnych (post)świadków tego, co wydarzyło się wcześniej.

\section{Bibliografia}

Aleksijewicz S.: Cynkowi chłopcy. Przeł. J. Czech. Wydawnictwo Czarne, Wołowiec 2015.

Artwińska A.: Gewalt legitimieren? Krieg und Affekte bei Svetlana Aleksijevič. In: Verbrechen, Fiktion, Vermarktung. Gewalt in den zeitgenössischen slavischen

z 19 października 2015 r. Dostępne w Internecie: https://wyborcza.pl/1,90535,18990702,ladunek200-ten-ohydny-wspanialy-zsrr.html [data dostępu: 18.03.2021]).

${ }^{31}$ Por. D. Laub: Bearing Witness or the Vicissitudes of Listening. In: Testimony: Crises of Witnessing in Literature, Psychoanalysis, and History. Eds. Sh. Felman, D. Laub. Routledge, New York 1992, s. 70-71.

${ }^{32}$ Por. M. Rothberg: The Implicated Subject..., s. 153. 
Literaturen. Hrsg. L. Burlon i in. Universitätsverlag Potsdam, Potsdam 2013, s. $161-175$.

Artwińska A.: We're Easy to Spot': Soviet Generation(s) after Soviet Era and the Invention of the Self in Svetlana Alexievich's "Secondhand Time: The Last of the Soviets". In: Gender, Generations, and Communism in Central and Eastern Europe and Beyond. Eds. A. Artwińska, A. Mrozik. Routledge, New York-London 2020, s. 227-247.

Bajor M.: Mój żołnierzyku. Dostępne w Internecie: https://www.michalbajor.pl/index. php?option=com_content\&view=article\&id=116:moj-zolnierzyku\&catid=17:tekstypiosenek\&Itemid=101 [data dostępu: 18.03.2021].

Bełza W.: Ołowiany żołnierz. W: W. Bełza: Ołowiany żołnierz i inne powiastki dla młodego wieku. Gebethner i Wolff, Warszawa 1909, s. 3-9.

Bratkowski S.: Książka o wyobraźni Rosjan. W: S. Aleksijewicz: Ołowiane żołnierzyki. Przeł. L. Wołosiuk. Kolegium Europy Wschodniej im. Jana Nowaka-Jeziorańskiego, Wrocław 2007, s. 5-6.

Couser Th.G.: Making, Taking, and Faking Lives. The Ethics of Collaborative Life Writing. "Style. Literature and Ethical Criticism" 1998, no 32/2, s. 334-350.

Ficowski J.: Każdy ślad cieniem wyrasta. W: J. Ficowski: Ołowiani żołnierze. Wydawnictwo Eugeniusza Kuthana, Warszawa-Kraków 1948, s. 4.

Haska A.: „Znałam tylko jedna żydóweczkę ukrywająca się...”. Sprawa Zofii i Mariana Chominów. „Zagłada Żydów. Studia i Materiały” 2008, nr 4, s. 392-407.

Kandziora J.: Tropy akowskie w poezji Jerzego Ficowskiego. „Poznańskie Studia Polonistyczne" 2012, nr 20 (40), s. 251-270.

Krämer S.: Vertrauen schenken. Über Ambivalenzen der Zeugenschaft. In: Politik der Zeugenschaft. Zur Kritik einer Wissenspraxis. Hrsg. S. Schmidt, S. Krämer, R. Voges. Transcript, Bielefeld 2011, s. 117-139.

Laub D.: Bearing Witness or the Vicissitudes of Listening. In: Testimony: Crises of Witnessing in Literature, Psychoanalysis, and History. Eds. Sh. Felman, D. Laub. Routledge, New York 1992, s. 57-74.

Lejeune Ph.: Die Autobiographie der Nicht-Schreiber. In: Texte zur Theorie der Biographie und Autobiographie. Hrsg. A. Tippner, Ch.F. Laferl. Reclam, Stuttgart 2016, s. $191-218$.

Lindbladh J.: The Problem of Narration and Reconciliation in Svetlana Aleksievich's Testimony "Voices from Chernobyl". In: The Poetics of Memory in Post-Totalitarian Narration. Ed. J. Lindbladh. Centre for European Studies, Lund 2008, s. 41-55.

Ołów. Dostępne w Internecie: https://pl.wikipedia.org/wiki/O\%C5\%82\%C3\%B3w\#CITEREFPolyanskiy1986 [data dostępu: 18.03.2021]. 
„Osteuropa“ 2018, Nr. 1-2: Nackte Seelen. Svetlana Aleksievič und der „Rote Mensch“. Hrsg. M. Sapper, A. Tippner, V. Weichsel.

Puto K.: Wielki kapitat chciał nas zatruć ołowiem. Nie tylko on. „Krytyka Polityczna” z 19 marca 2021 r. Dostępne w Internecie: https://krytykapolityczna.pl/swiat/wielkikapital-chcial-nas-zatruc-olowiem-nie-tylko-on/ [data dostępu: 18.03.2021].

Radziwinowicz W.: „Eadunek 200”. Ten ohydny wspanialy ZSRR. „Gazeta Wyborcza” z 19 października 2015 r. Dostępne w Internecie: https://wyborcza. pl/1,90535,18990702,ladunek-200-ten-ohydny-wspanialy-zsrr.html [data dostępu: 18.03.2021].

Rothberg M.: The Implicated Subject. Beyond Victims and Perpetrators. Stanford University Press, Stanford 2019.

Sanders M.A.: Theorizing the Collaborative Self: The Dynamics of Contour and Content in the Dictated Autobiography. "New Literary History" 1994, Vol. 25, no 2: Writers on Writers, s. 445-458.

Szczęsny A.: „Ołowiane żotnierzyki” czy „Cynkowi chłopcy”? Przypisy tłumacza jako kryterium analizy serii tłumaczeniowej. „Między Oryginałem a Przekładem” 2016, nr 2 (32), s. 103-119.

Wójcińska A.: Nikogo nie zmuszam, sami mówią. [Rozmowa ze Swietłaną Aleksijewicz]. „Polityka” 2015, nr 42, s. 38-42.

Anna ARtwińska - profesor w Instytucie Slawistyki Uniwersytetu w Lipsku. Autorka książki Poeta w stużbie polityki. O Mickiewiczu w PRL i Goethem w NRD (2008 i 2014). Współredaktorka tomów Po Zagładzie. Narracje postkatastroficzne (2015), Studies on Socialist Realism. The Polish View (2015). Członkini Rady Naukowej czasopisma „Narracje o Zagładzie”. 